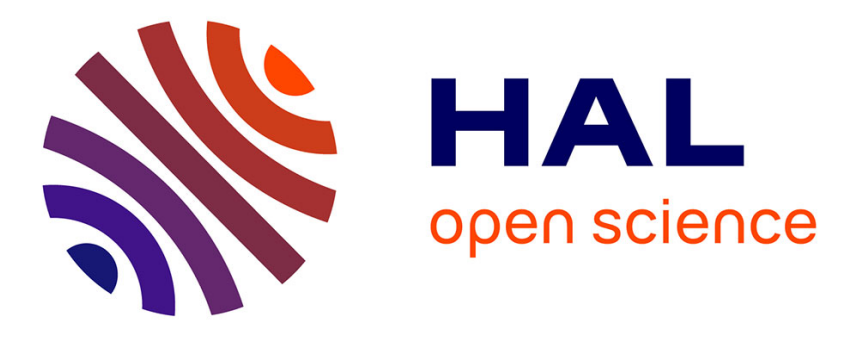

\title{
Altered oxidant-mediated intraneuronal zinc mobilization in a triple transgenic mouse model of alzheimer's disease
}

Stefano L. Sensi, Ilario G. Rapposelli, Valerio Frazzini, Nicola Mascetra

\section{- To cite this version:}

Stefano L. Sensi, Ilario G. Rapposelli, Valerio Frazzini, Nicola Mascetra. Altered oxidant-mediated intraneuronal zinc mobilization in a triple transgenic mouse model of alzheimer's disease. Experimental Gerontology, 2008, 43 (5), pp.488. 10.1016/j.exger.2007.10.018 . hal-00499035

\section{HAL Id: hal-00499035 https://hal.science/hal-00499035}

Submitted on 9 Jul 2010

HAL is a multi-disciplinary open access archive for the deposit and dissemination of scientific research documents, whether they are published or not. The documents may come from teaching and research institutions in France or abroad, or from public or private research centers.
L'archive ouverte pluridisciplinaire HAL, est destinée au dépôt et à la diffusion de documents scientifiques de niveau recherche, publiés ou non, émanant des établissements d'enseignement et de recherche français ou étrangers, des laboratoires publics ou privés. 


\section{Accepted Manuscript}

Altered oxidant-mediated intraneuronal zinc mobilization in a triple transgenic mouse model of alzheimer's disease

Stefano L. Sensi, Ilario G. Rapposelli, Valerio Frazzini, Nicola Mascetra

PII:

S0531-5565(07)00250-1

DOI:

10.1016/j.exger.2007.10.018

Reference:

EXG 8409

To appear in:

Experimental Gerontology

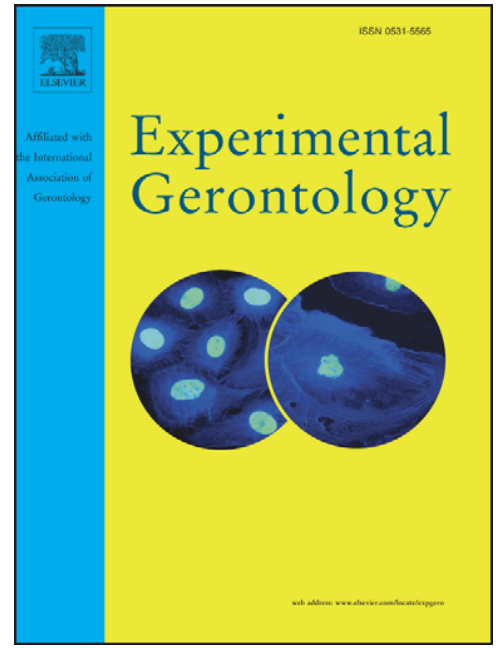

Received Date: $\quad 1$ October 2007

Accepted Date: $\quad 30$ October 2007

Please cite this article as: Sensi, S.L., Rapposelli, I.G., Frazzini, V., Mascetra, N., Altered oxidant-mediated intraneuronal zinc mobilization in a triple transgenic mouse model of alzheimer's disease, Experimental Gerontology (2007), doi: 10.1016/j.exger.2007.10.018

This is a PDF file of an unedited manuscript that has been accepted for publication. As a service to our customers we are providing this early version of the manuscript. The manuscript will undergo copyediting, typesetting, and review of the resulting proof before it is published in its final form. Please note that during the production process errors may be discovered which could affect the content, and all legal disclaimers that apply to the journal pertain. 


\section{ALTERED OXIDANT-MEDIATED INTRANEURONAL ZINC MOBILIZATION IN A TRIPLE TRANSGENIC MOUSE MODEL OF ALZHEIMER'S DISEASE}

Stefano L. Sensi ${ }^{1,2,3 *}$, Ilario G. Rapposelli ${ }^{1}$, Valerio Frazzini ${ }^{1}$ and Nicola Mascetra ${ }^{1}$

${ }^{1}$ Department of Basic and Applied Medical Science, Molecular Neurology Unit, CeSI-Center for Excellence on Aging, University 'G. d'Annunzio', Chieti, 66013, Italy

${ }^{2}$ Department of Neurology, University of California, Irvine, Irvine, CA, 92697-4292

${ }^{3}$ Department of Neurology, University of Texas Medical Branch, Galveston, Galveston, TX 775550539

*To whom correspondence should be addressed at:

Telephone: (39) 0871-541544; Fax: (39) 0871-541542; E-mail: ssensi@uci.edu

Running title: $3 \times \mathrm{Tg}-\mathrm{AD}$, ROS and $\left[\mathrm{Zn}^{2+}\right]_{\mathrm{i}}$ rises

KEY WORDS: synaptic zinc homeostasis, oxidative stress, $3 \mathrm{xTg}-\mathrm{AD}, \mathrm{PS} 1_{\mathrm{KI}}$, presenilin, tau, amyloid, Alzheimer's disease, neuronal death 


\section{Abstract:}

Alzheimer's disease (AD) is responsible for the most common form of dementia among elderly people. Signature features of the AD brain are intra/extracellular deposits of $\beta$-amyloid (A $\beta$ ) and neurofibrillary tangles composed of hyperphosphorylated tau. Recent evidence indicates that in AD altered $\mathrm{Zn}^{2+}$ homeostasis can play an important role in the development of the disease as the cation promotes $A \beta$ oligomerization and plaque formation. In this study, we investigated whether intraneuronal $\mathrm{Zn}^{2+}$ homeostasis is affected by known "pro-AD factors" such as mutant forms of the amyloid precursor (APP), presenilin-1 (PS1), and tau proteins. Oxidative stress is a potent trigger for mobilization of intracellular free $\mathrm{Zn}^{2+}\left(\left[\mathrm{Zn}^{2+}\right]_{\mathrm{i}}\right)$ and we therefore evaluated ROS-driven $\left[\mathrm{Zn}^{2+}\right]_{\mathrm{i}}$ rises in neurons obtained from triple transgenic AD mice (3xTg-AD) that express mutant APP, PS1 and tau. In this study, $\left[\mathrm{Zn}^{2+}\right]_{\mathrm{i}}$ rises triggered by prolonged exposure to the membrane-permeant oxidizing agent 2,2'-dithiodipyridine were found to be significantly higher in 3xTg-AD neurons when compared to control cultures, suggesting that neuronal expression of pro-AD factors can facilitate altered $\mathrm{Zn}^{2+}$ homeostasis. 


\section{INTRODUCTION}

Alzheimer's disease (AD) is the most common neurodegenerative disorder of the aging brain.

$\mathrm{AD}$ is associated with the appearance of parenchymal deposits of $\beta$-amyloid $(\mathrm{A} \beta)$ and neurofibrillary tangles made of hyperphosphorylated-tau protein (h-tau) surrounded by altered neuritic processes and reactive glia. Growing evidence suggests that alteration in $\mathrm{Zn}^{2+}$ levels is an important contributing factor in $\mathrm{AD}$ as the cation can induce $\mathrm{A} \beta$ oligomerization and plaque formation (Frederickson et al., 2005).

$\mathrm{Zn}^{2+}$ is a potent mediator of neuronal death (Sensi and Jeng, 2004) and intraneuronal $\mathrm{Zn}^{2+}$ $\left(\left[\mathrm{Zn}^{2+}\right]_{\mathrm{i}}\right)$ homeostasis is tightly controlled by a balance between influx, sequestration, buffering, and extrusion. Most $\mathrm{Zn}^{2+}$ enters neurons through $\mathrm{Ca}^{2+}$-permeable glutamate receptors (i.e: the NMDA and divalent-permeable AMPA receptors) and voltage-sensitive $\mathrm{Ca}^{2+}$ channels (Sensi et al., 1997). $\mathrm{Zn}^{2+}$ buffering and sequestration are largely controlled by $\mathrm{Zn}^{2+}$-binding proteins (metallothioneins; MTs) and mitochondria, while extrusion is mediated by the activity of several $\mathrm{Zn}^{2+}$ transporters (Sekler et al., 2007).

$\mathrm{Zn}^{2+}$ binding to MTs is greatly affected by changes in the redox state of the two $\mathrm{Zn}^{2+} / \mathrm{Cysteine}$ cluster regions. Recent studies indicate that endogenous reactive oxygen species (ROS) or exogenous oxidants are able to promote harmful $\mathrm{Zn}^{2+}$ release from MTs (Aizenman et al., 2000; Bossy-Wetzel et al., 2004; Maret, 2000). MTs are present in the central nervous system in three isoforms (MT1, 2 and 3), but, while MT1 and MT2 are expressed in astrocytes, MT3 is selectively expressed in neurons (Aschner, 1996), thereby representing a potential injurious source of releasable $\mathrm{Zn}^{2+}$ inside of neurons (Lee et al., 2003).

$\mathrm{Zn}^{2+}$ is sequestered by mitochondria (reviewed in Sensi and Jeng, 2004; Gazaryan et al., 2007; Malaiyandi et al., 2005) and, notably, mitochondrial $\mathrm{Zn}^{2+}$ can be re-released into the cytosol in a $\mathrm{Ca}^{2+}$-dependent fashion (Frazzini et al., 2007; Sensi et al., 2003). Mitochondrial $\mathrm{Zn}^{2+}$ accumulation is not always a benign process as the cation can potently disrupt mitochondrial function and 
promote strong oxidative stress as well as neuronal death (Brown et al., 2000; Gazaryan et al., 2007;

Malaiyandi et al., 2005; Sensi et al., 1999).

Recent studies suggest ways by which disruption of $\mathrm{Zn}^{2+}$ homeostasis might play a role in $\mathrm{AD}$ related neurodegeneration (Frederickson et al., 2005; Religa et al., 2006). Expression levels of $\mathrm{Zn}^{2+}$ transporters such as ZnT1, ZnT4 and ZnT6 are altered in the brain of individuals affected by mild cognitive impairment (MCI) and AD (Lovell et al., 2005; Lovell et al., 2006). Furthermore, studies in $\mathrm{AD}$ animal models have shown that genetic ablation of synaptic $\mathrm{Zn}^{2+}$ (Lee et al., 2002) or use of $\mathrm{Zn}^{2+}$ chelators can have a significant effect on brain accumulation of $\mathrm{A} \beta$ (Cherny et al., 2001; Lee et al., 2002; Lee et al., 2004). Further substantiating a role for $\mathrm{Zn}^{2+}$ unbalance in $\mathrm{AD}$, a recent phase II clinical trial employing the cell-permeable $\mathrm{Zn}^{2+} / \mathrm{Cu}^{2+}$ modulator clioquinol has been reported to produce a significant decrease in the rate of cognitive decline in a subset of AD patients (Ritchie et al., 2003).

Oxidative stress is an additional contributing factor in AD (Butterfield et al., 2001) and in this study, we investigated whether expression of pro-AD factors such as mutant forms of the amyloid precursor protein (APP), presenilin-1 (PS1) and tau protein can modulate ROS-mediated $\left[\mathrm{Zn}^{2+}\right]_{\mathrm{i}}$ rises in cultured cortical neurons obtained from a triple transgenic mouse model of $\mathrm{AD}(3 \mathrm{xTg}-\mathrm{AD})$. 3xTg-AD mice display the major pathological features of the AD brain, including progressive and age-dependent $A \beta$ and tau pathology, and show an early (at 4-6 month of age) intraneuronal accumulation of $\mathrm{A} \beta$ in $\mathrm{AD}$-vulnerable hippocampal neurons that well correlates with concomitant appearance of signs of altered synaptic plasticity and cognitive deficits (Billings et al., 2005; Oddo et al., 2003). 


\section{MATERIALS AND METHODS}

Materials. FluoZin-3 AM and Newport Green diacetate were purchased from Molecular Probes (Invitrogen, Milan, Italy). 2,2'-dithiodipyridine (DTDP) was purchased from Sigma-Aldrich (Milan, Italy). Tissue culture media and serum were from Gibco (Invitrogen, Milan, Italy). All other chemicals and reagents were obtained from common commercial sources.

Animal cell cultures. All animal procedures were approved by our institutional animal care and use committee, and are in accordance with the NIH "Principles of laboratory animal care" and national laws. Murine cortical cultures were prepared from embryonic 3xTg-AD, presenilin-1 knock-in $\left(\mathrm{PS}_{\mathrm{KI}}\right)$, and non-Tg $(\mathrm{CD} 1)$ mice. Neurons were plated upon astrocytic monolayers on poly-lysine + laminin coated coverslips as previously described (Sensi et al., 1999).

$\left[\mathrm{Zn}^{2+}\right]_{i}$ imaging studies. $\left[\mathrm{Zn}^{2+}\right]$ imaging was carried out using an inverted microscope coupled to a xenon lamp, a PC-controlled filter wheel, a 40X, epifluorescence oil immersion objective, and fluorescent cubes. Cultures (at 7 D.I.V.) were loaded in the dark, with Newport Green diacetate (3 $\mu \mathrm{M})$ or FluoZin-3 AM (5 $\mu \mathrm{M})$ in a HEPES-buffered medium (HCSS) whose composition was (in $\mathrm{mM}$ ): $120 \mathrm{NaCl}, 5.4 \mathrm{KCl}, 0.8 \mathrm{MgCl}_{2}, 20$ HEPES, 15 glucose, $1.8 \mathrm{CaCl}_{2}, 10 \mathrm{NaOH}$, pH 7.4, for 30 min at $25^{\circ} \mathrm{C}$, then washed in HCSS and kept in the dark for an additional 30 min; excitation was at $490 \mathrm{~nm}$ and emission at $530 \mathrm{~nm}$. Experiments were carried out at room temperature $\left(25^{\circ} \mathrm{C}\right)$. Drugs were applied by bath application and removed through a rapid flow exchange system. Images were acquired with a 12 bit digital CCD camera (ORCA-HR, Hamamatsu, Bridgewater, NJ) and analyzed (after background subtraction from a cell-free region of the dish) with Metafluor 6.0 imaging software (Universal Imaging Corporation, Downingtown, PA). Fluorescence values where then converted in $\left[\mathrm{Zn}^{2+}\right]_{\mathrm{i}}$ calibrated values by employing the following equation: $\left[\mathrm{Zn}^{2+}\right]_{i}=\mathrm{K}_{\mathrm{d}}(\mathrm{F}-$ $\left.\mathrm{F}_{\min }\right) /\left(\mathrm{F}_{\max }-\mathrm{F}\right)$ where $\mathrm{K}_{\mathrm{d}}$ is $15 \mathrm{nM}\left(\right.$ FluoZin-3) or $1 \mu \mathrm{M}$ (Newport Green). $\mathrm{F}_{\max }$ was obtained at 
the end of each experiment by adding the $\mathrm{Zn}^{2+}$-selective ionophore $\mathrm{Na}^{+}$-pyrithione $(10 \mu \mathrm{M})$ in the

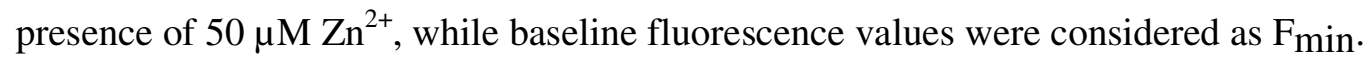

Experiment replication and statistics. All experiments reported represent at least 3 independent replications. Comparisons were obtained by Student-Newman-Keuls' test $(p<0.001)$.

\section{RESULTS}

To evaluate dynamic changes in $\left[\mathrm{Zn}^{2+}\right]_{\mathrm{i}}$ levels, cultured (7 D.I.V.) cortical neurons obtained from 3xTg-AD and control mice were loaded with the $\mathrm{Zn}^{2+}$-selective fluorescent probes FluoZin-3 or Newport Green (Gee et al., 2002; Sensi et al., 1999). 3xTg-AD mice have been developed by LaFerla and colleagues by introducing two transgenes $\left(\mathrm{APP}_{\text {swe }}\right.$ and tau $\left.\mathrm{P}_{\mathrm{P} 301 \mathrm{~L}}\right)$ into the germline of the mutant PS1 $1_{\mathrm{M} 146 \mathrm{~V}}$ knock-in mouse (Oddo et al., 2003), and therefore, in our study, ROS-mediated $\left[\mathrm{Zn}^{2+}\right]_{\mathrm{i}}$ rises in $3 \times \mathrm{Tg}-\mathrm{AD}$ neurons were compared with both $\mathrm{PS} 1_{\mathrm{KI}}$ and non-Tg cultures considered as controls. Probe loaded cultures were exposed to the oxidizing compound 2,2'-dithiodipyridine (DTDP) and changes in either FluoZin-3 or Newport Green fluorescence units converted in calibrated $\left[\mathrm{Zn}^{2+}\right]_{\mathrm{i}}$ values. In pilot experiments, we evaluated DTDP-driven $\left[\mathrm{Zn}^{2+}\right]_{\mathrm{i}}$ rises in $3 \mathrm{xTg}-\mathrm{AD}$ (and control) neurons loaded with Newport Green, a $\mathrm{Zn}^{2+}$-sensitive probe that shows an intermediate affinity $\left(\mathrm{K}_{\mathrm{d}}=1 \mu \mathrm{M}\right)$ for the cation. In these experiments, exposure to different DTDP concentrations (up to $200 \mu \mathrm{M}$ ) failed to promote any significant $\mathrm{Zn}^{2+}$-dependent fluorescence increase, indicating that DTDP-mediated $\left[\mathrm{Zn}^{2+}\right]_{\mathrm{i}}$ rises were in a (sub-micromolar) range not detectable by the probe (data not shown). We then repeated the DTDP challenge in 3xTg-AD, $\mathrm{PS}_{\mathrm{KI}}$ and non-Tg neurons loaded with the high affinity $\left(\mathrm{K}_{\mathrm{d}}=15 \mathrm{nM}\right) \mathrm{Zn}^{2+}$-selective probe 
FluoZin-3 and evaluated $\left[\mathrm{Zn}^{2+}\right]_{\mathrm{i}}$ rises in the three cultures. In these experiments, DTDP exposure was found capable to promote detectable increases in probe fluorescence. A set of dose-finding experiments (i.e.: DTDP concentrations ranging from 10 to $50 \mu \mathrm{M}$ ) indicated that DTDP at $50 \mu \mathrm{M}$ is sufficient to bring $\left[\mathrm{Zn}^{2+}\right]_{\mathrm{i}}$ transients to saturating molar values $(>150 \mathrm{nM})$ that are not suitable for reliable quantification with FluoZin-3, while optimal $\left[\mathrm{Zn}^{2+}\right]_{\mathrm{i}}$ excursions could be obtained with prolonged (10 min) exposure to $25 \mu \mathrm{M}$ DTDP (Fig.1). FluoZin-3 loaded AD and control cultures showed no differences in basal $\left[\mathrm{Zn}^{2+}\right]_{\mathrm{i}}$ levels, while analysis of peak $\left[\mathrm{Zn}^{2+}\right]_{\mathrm{i}}$ rises obtained upon exposure to DTDP $(25 \mu \mathrm{M} ; 10 \mathrm{~min})$ revealed significantly higher levels in 3xTg-AD neurons (mean \pm SEM: $20.17 \pm 3.76 \mathrm{nM})$ when compared with PS1 $1_{\mathrm{KI}}(5.51 \pm 0.74 \mathrm{nM})$ and non-Tg cultures $(0.10$ $\pm 0.15 \mathrm{nM} ; \mathrm{p}<0.001$; Fig.2A). Peak $\left[\mathrm{Zn}^{2+}\right]_{\mathrm{i}}$ rises in $\mathrm{PS} 1_{\mathrm{KI}}$ neurons were significantly greater than those observed in non-Tg neurons $(\mathrm{p}<0.001)$. To better estimate the extent of DTDP-mediated $\left[\mathrm{Zn}^{2+}\right]_{\mathrm{i}}$ increases, we also performed an integral analysis of the overall cytosolic $\mathrm{Zn}^{2+}$ overload occurring during the 10 minute exposure to the oxidant. Confirming what observed in the case of peak $\left[\mathrm{Zn}^{2+}\right]_{\mathrm{i}}$ levels, cytosolic $\mathrm{Zn}^{2+}$ overload was found to be significantly higher $(\mathrm{p}<0.001)$ in 3xTg-AD cultures (Fig. 2B).

\section{DISCUSSION}

Results presented in this study indicate that expression of pro-AD factors such mutant APP, PS1, and tau can facilitate perturbation of intraneuronal $\mathrm{Zn}^{2+}$ homeostasis.

DTDP can catalyze disulfide exchange and mobilizes $\mathrm{Zn}^{2+}$ from MTs in vitro (Jiang et al., 1998) thus, the intraneuronal $\left[\mathrm{Zn}^{2+}\right]_{\mathrm{i}}$ rises observed upon DTDP exposure are likely due to $\mathrm{Zn}^{2+}$ release from MTs. It should be pointed out that altered $\mathrm{Zn}^{2+}$ homeostasis, MTs expression, and increased oxidative stress are all playing a critical role in AD and brain aging (Mocchegiani et al., 2005). 
In $\mathrm{AD}, \mathrm{A} \beta$ generates ROS (Behl et al., 1994) and can thereby promote ROS-driven $\left[\mathrm{Zn}^{2+}\right]_{\mathrm{i}}$ release. $\left[\mathrm{Zn}^{2+}\right]_{\mathrm{i}}$ accumulation can, in turn, trigger potent mitochondrial dysfunction and further ROS generation (reviewed in Sensi and Jeng, 2004). Thus, $\mathrm{Zn}^{2+}$-induced oxidative stress can act as a catalyst and enhancer of a self-perpetuating vicious cycle.

AD-associated alterations in $\left[\mathrm{Zn}^{2+}\right]_{\mathrm{i}}$ homeostasis can have profound implications for the progression of the disease by interfering with $\mathrm{A} \beta$ oligomerization. Recent developments in $\mathrm{AD}$ research strongly support the view that the severity of neuronal loss and dementia is mediated by soluble $\mathrm{A} \beta$ oligomers, rather than fibrillar and insoluble deposits of $\mathrm{A} \beta$ (reviewed in LaFerla et al., 2007). There is compelling evidence that, in the brains of AD subjects and AD animal models, levels of soluble $A \beta$ species correlate better with cognitive decline than plaque density (Gong et al., 2003; Lesne et al., 2006; Lue et al., 1999; Naslund et al., 2000; Oddo et al., 2006a). Studies in brains from $\mathrm{AD}$ patients and $\mathrm{AD}$ animal models have shown that formation of $\mathrm{A} \beta$ oligomers is initiated intracellularly rather than in the extracellular space (Walsh et al., 2000; Oddo et al., 2006b) and indicated that such process potently impairs synaptic transmission.

In this scenario, altered levels of intraneuronal $\mathrm{Zn}^{2+}$ might exert a critical role in setting the stage for the formation of an early nidus of intrasynaptic oligomerization of $A \beta$.

It should be also underlined that brain aging is the major risk factor for $\mathrm{AD}$ and is a potently disrupting $\mathrm{Zn}^{2+}$ homeostasis. Animal studies in neurons from aging hippocampi indicate that MT3 expression is more abundant compared to young hippocampal extracts (Giacconi et al., 2003). MTs are potent antioxidants and protective factors against stress conditions and increased MT expression in the aging brain may simply reflect a protective endogenous response to a sub-chronic state of inflammatory and/or oxidative stress. On the other hand, it is conceivable that protective actions of MTs can be overridden by a concomitant increase in ROS-driven $\left[\mathrm{Zn}^{2+}\right]_{\mathrm{i}}$ levels. As in the aging brain (and even more so in the AD brain) there is an increase in free radical generation, it is possible that ROS induce a chronic MT up-regulation that leads to higher intracellular availability of 
releasable $\mathrm{Zn}^{2+}$ (Mocchegiani et al., 2001; Mocchegiani et al., 2004). Finally, it should be considered that aging and AD greatly affect mitochondrial capability to cope with both cation loads and oxidative stress and these conditions are associated with increased mutations of mitochondrial DNA as well as expression of defective mitochondrial proteins (Raule et al., 2007; Wallace, 2005), thereby setting the stage for a self-perpetuating vicious cycle.

In summary, in light of the pivotal role played by oxidative stress and $\left[\mathrm{Zn}^{2+}\right]_{\mathrm{i}}$ unbalance in ADrelated neuronal degeneration, our study suggests an intriguing interplay between free radical production and pro-AD factors in the generation of altered $\left[\mathrm{Zn}^{2+}\right]_{\mathrm{i}}$ homeostasis. Further investigations are needed to elucidate the pathways involved and how brain aging can modulate this pathological process. 


\section{Figure legends}

Fig. 1. Time course of DTDP-mediated $\left[\mathrm{Zn}^{2+}\right]_{\mathrm{i}}$ rises in neurons isolated from $3 \times T$ T-AD, PS1 $1_{\mathrm{KI}}$, and non-Tg cortical neurons. FluoZin-3 loaded 3xTg-AD (•), $\operatorname{PS}_{\mathrm{KI}}(\bullet)$, and non-Tg (०) neuronal cultures were imaged before and during a 10 min exposure to $25 \mu \mathrm{M}$ DTDP. Traces show mean ( \pm SEM) $\left[\mathrm{Zn}^{2+}\right]_{i}$ rises in 15-27 neurons from one experiment representative of 3.

Fig. 2. DTDP promotes different degrees of $\left[\mathrm{Zn}^{2+}\right]_{\mathrm{i}}$ mobilization in $3 \times \mathrm{Xg}-\mathrm{AD}, \mathrm{PS1}_{\mathrm{KI}}$, and nonTg cultured neurons. (A) FluoZin-3 loaded transgenic (3xTg-AD, PS1 $\left.1_{\mathrm{KI}}\right)$ and non-transgenic cortical neurons were exposed to DTDP (same paradigm as in Fig.1) and peak $\left[\mathrm{Zn}^{2+}\right]_{\mathrm{i}}$ levels evaluated. Bar graph depicts peak $\left[\mathrm{Zn}^{2+}\right]_{\mathrm{i}}$ rises (mean $\pm \mathrm{SEM}$ ) of $>48$ neurons from the three different cultures ( $\mathrm{n}=3$ for each condition). (B) Bar graph depicts the area under the curve of $\left[\mathrm{Zn}^{2+}\right]_{\mathrm{i}}$ loads (mean \pm SEM) of a 10 min DTDP exposure. * and \# indicate differences between $3 \times \mathrm{Tg}-\mathrm{AD}$ and $\mathrm{PS} 1_{\mathrm{KI}}$ or PS1 $1_{\mathrm{KI}}$ and non-Tg neurons, respectively $(p<0.001)$.

\section{Acknowledgements}

We thank Antonello Pantalone and Teresa Caporale for expert assistance with neuronal cultures. This work was supported by FIRB 2003 and PRIN 2006 grants (SLS). 


\section{References}

Aizenman, E., Stout, A.K., Hartnett, K.A., Dineley, K.E., McLaughlin, B., Reynolds, I.J., 2000. Induction of neuronal apoptosis by thiol oxidation: putative role of intracellular zinc release. $\mathrm{J}$ Neurochem 75, 1878-88.

Aschner, M., 1996. The functional significance of brain metallothioneins. Faseb J 10, 1129-36.

Behl, C., Davis, J.B., Lesley, R., Schubert, D., 1994. Hydrogen peroxide mediates amyloid beta protein toxicity. Cell 77, 817-27.

Billings, L.M., Oddo, S., Green, K.N., McGaugh, J.L., LaFerla, F.M., 2005. Intraneuronal Abeta causes the onset of early Alzheimer's disease-related cognitive deficits in transgenic mice. Neuron $45,675-88$.

Bossy-Wetzel, E., Talantova, M.V., Lee, W.D., Scholzke, M.N., Harrop, A., Mathews, E., Gotz, T., Han, J., Ellisman, M.H., Perkins, G.A., Lipton, S.A., 2004. Crosstalk between nitric oxide and zinc pathways to neuronal cell death involving mitochondrial dysfunction and p38-activated $\mathrm{K}+$ channels. Neuron 41, 351-65.

Brown, A.M., Kristal, B.S., Effron, M.S., Shestopalov, A.I., Ullucci, P.A., Sheu, K.F., Blass, J.P., Cooper, A.J., 2000. Zn2+ inhibits alpha-ketoglutarate-stimulated mitochondrial respiration and the isolated alpha-ketoglutarate dehydrogenase complex. J Biol Chem 275, 13441-7.

Butterfield, D.A., Drake, J., Pocernich, C., Castegna, A., 2001. Evidence of oxidative damage in Alzheimer's disease brain: central role for amyloid beta-peptide. Trends Mol Med 7, 548-54.

Cherny, R.A., Atwood, C.S., Xilinas, M.E., Gray, D.N., Jones, W.D., McLean, C.A., Barnham, K.J., Volitakis, I., Fraser, F.W., Kim et, a., 2001. Treatment with a copper-zinc chelator markedly and rapidly inhibits beta-amyloid accumulation in Alzheimer's disease transgenic mice. Neuron 30, 665-676. 
Frazzini, V., Rapposelli, I.G., Corona, C., Rockabrand, E., Canzoniero, L.M., Sensi, S.L., 2007. Mild Acidosis Enhances Ampa Receptor-Mediated Intracellular Zinc Mobilization in Cortical Neurons. Mol Med 13, 356-361.

Frederickson, C.J., Koh, J.Y., Bush, A.I., 2005. The neurobiology of zinc in health and disease. Nat Rev Neurosci 6, 449-62.

Gazaryan, I.G., Krasinskaya, I.P., Kristal, B.S., Brown, A.M., 2007. Zinc irreversibly damages major enzymes of energy production and antioxidant defense prior to mitochondrial permeability transition. J Biol Chem 282, 24373-80.

Gee, K.R., Zhou, Z.L., Ton-That, D., Sensi, S.L., Weiss, J.H., 2002. Measuring zinc in living cells. A new generation of sensitive and selective fluorescent probes. Cell Calcium 31, 245-51.

Giacconi, R., Cipriano, C., Muzzioli, M., Gasparini, N., Orlando, F., Mocchegiani, E., 2003. Interrelationships among brain, endocrine and immune response in ageing and successful ageing: role of metallothionein III isoform. Mech Ageing Dev 124, 371-8.

Gong, Y., Chang, L., Viola, K.L., Lacor, P.N., Lambert, M.P., Finch, C.E., Krafft, G.A., Klein, W.L., 2003. Alzheimer's disease-affected brain: presence of oligomeric A beta ligands (ADDLs) suggests a molecular basis for reversible memory loss. Proc Natl Acad Sci U S A 100, 10417-22.

Jiang, L.-J., Maret, W., Vallee, B.L., 1998. The glutathione redox couple modulates zinc transfer from metallothionein to zinc-depleted sorbitol dehydrogenase. Proc. Natl. Acad. Sci. USA 95, $3483-3488$.

LaFerla, F.M., Green, K.N., Oddo, S., 2007. Intracellular amyloid-beta in Alzheimer's disease. Nat Rev Neurosci 8, 499-509.

Lee, J.Y., Cole, T.B., Palmiter, R.D., Suh, S.W., Koh, J.Y., 2002. Contribution by synaptic zinc to the gender-disparate plaque formation in human Swedish mutant APP transgenic mice. Proc Natl Acad Sci U S A 99, 7705-10. 
Lee, J.Y., Kim, J.H., Palmiter, R.D., Koh, J.Y., 2003. Zinc released from metallothionein-iii may contribute to hippocampal CA1 and thalamic neuronal death following acute brain injury. Exp Neurol 184, 337-47.

Lee, J.Y., Friedman, J.E., Angel, I., Kozak, A., Koh, J.Y., 2004. The lipophilic metal chelator DP109 reduces amyloid pathology in brains of human beta-amyloid precursor protein transgenic mice. Neurobiol Aging 25, 1315-21.

Lesne, S., Koh, M.T., Kotilinek, L., Kayed, R., Glabe, C.G., Yang, A., Gallagher, M., Ashe, K.H., 2006. A specific amyloid-beta protein assembly in the brain impairs memory. Nature 440, 352-7.

Lovell, M.A., Smith, J.L., Xiong, S., Markesbery, W.R., 2005. Alterations in zinc transporter protein-1 (ZnT-1) in the brain of subjects with mild cognitive impairment, early, and late-stage Alzheimer's disease. Neurotox Res 7, 265-71.

Lovell, M.A., Smith, J.L., Markesbery, W.R., 2006. Elevated zinc transporter-6 in mild cognitive impairment, Alzheimer disease, and pick disease. J Neuropathol Exp Neurol 65, 489-98.

Lue, L.F., Kuo, Y.M., Roher, A.E., Brachova, L., Shen, Y., Sue, L., Beach, T., Kurth, J.H., Rydel, R.E., Rogers, J., 1999. Soluble amyloid beta peptide concentration as a predictor of synaptic change in Alzheimer's disease. Am J Pathol 155, 853-62.

Malaiyandi, L.M., Vergun, O., Dineley, K.E., Reynolds, I.J., 2005. Direct visualization of mitochondrial zinc accumulation reveals uniporter-dependent and -independent transport mechanisms. J Neurochem 93, 1242-50.

Maret, W., 2000. The Function of Zinc Metallothionein: A Link between Cellular Zinc and Redox State. J. Nutr. 130, 1455S-1458.

Mocchegiani, E., Giacconi, R., Cipriano, C., Muzzioli, M., Fattoretti, P., Bertoni-Freddari, C., Isani, G., Zambenedetti, P., Zatta, P., 2001. Zinc-bound metallothioneins as potential biological markers of ageing. Brain Res Bull 55, 147-53. 
Mocchegiani, E., Giacconi, R., Fattoretti, P., Casoli, T., Cipriano, C., Muti, E., Malavolta, M., DiStefano, G., Bertoni-Freddari, C., 2004. Metallothionein isoforms (I+II and III) and interleukin-6 in the hippocampus of old rats: may their concomitant increments lead to neurodegeneration? Brain Res Bull 63, 133-42.

Mocchegiani, E., Bertoni-Freddari, C., Marcellini, F., Malavolta, M., 2005. Brain, aging and neurodegeneration: role of zinc ion availability. Prog Neurobiol 75, 367-90.

Naslund, J., Haroutunian, V., Mohs, R., Davis, K.L., Davies, P., Greengard, P., Buxbaum, J.D., 2000. Correlation between elevated levels of amyloid beta-peptide in the brain and cognitive decline. Jama 283, 1571-7.

Oddo, S., Caccamo, A., Shepherd, J.D., Murphy, M.P., Golde, T.E., Kayed, R., Metherate, R., Mattson, M.P., Akbari, Y., LaFerla, F.M., 2003. Triple-transgenic model of Alzheimer's disease with plaques and tangles: intracellular Abeta and synaptic dysfunction. Neuron 39, 409-21.

Oddo, S., Vasilevko, V., Caccamo, A., Kitazawa, M., Cribbs, D.H., LaFerla, F.M., 2006a. Reduction of soluble Abeta and tau, but not soluble Abeta alone, ameliorates cognitive decline in transgenic mice with plaques and tangles. J Biol Chem 281, 39413-23.

Oddo, S., Caccamo, A., Smith, I.F., Green, K.N., LaFerla, F.M., 2006b. A dynamic relationship between intracellular and extracellular pools of Abeta. Am J Pathol 168, 184-94.

Raule, N., Sevini, F., Santoro, A., Altilia, S., Franceschi, C., 2007. Association studies on human mitochondrial DNA: methodological aspects and results in the most common age-related diseases. Mitochondrion 7, 29-38.

Religa, D., Strozyk, D., Cherny, R.A., Volitakis, I., Haroutunian, V., Winblad, B., Naslund, J., Bush, A.I., 2006. Elevated cortical zinc in Alzheimer disease. Neurology 67, 69-75.

Ritchie, C.W., Bush, A.I., Mackinnon, A., Macfarlane, S., Mastwyk, M., MacGregor, L., Kiers, L., Cherny, R., Li, Q.X., Tammer, A., Carrington, D., Mavros, C., Volitakis, I., Xilinas, M., Ames, D., Davis, S., Beyreuther, K., Tanzi, R.E., Masters, C.L., 2003. Metal-protein attenuation with 
iodochlorhydroxyquin (clioquinol) targeting Abeta amyloid deposition and toxicity in Alzheimer disease: a pilot phase 2 clinical trial. Arch Neurol 60, 1685-91.

Sekler, I., Sensi, S.L., Hershfinkel, M., Silverman, W.F., 2007. Mechanism and regulation of cellular zinc transport. Mol Med 13, 337-43.

Sensi, S.L., Canzoniero, L.M., Yu, S.P., Ying, H.S., Koh, J.Y., Kerchner, G.A., Choi, D.W., 1997. Measurement of intracellular free zinc in living cortical neurons: routes of entry. J Neurosci 17, 9554-64.

Sensi, S.L., Yin, H.Z., Carriedo, S.G., Rao, S.S., Weiss, J.H., 1999. Preferential Zn2+ influx through $\mathrm{Ca} 2+$-permeable AMPA/kainate channels triggers prolonged mitochondrial superoxide production. Proc Natl Acad Sci U S A 96, 2414-9.

Sensi, S.L., Ton-That, D., Sullivan, P.G., Jonas, E.A., Gee, K.R., Kaczmarek, L.K., Weiss, J.H., 2003. Modulation of mitochondrial function by endogenous Zn2+ pools. PNAS 100, 6157-6162.

Sensi, S.L., Jeng, J.M., 2004. Rethinking the excitotoxic ionic milieu: the emerging role of $\mathrm{Zn}(2+)$ in ischemic neuronal injury. Curr Mol Med 4, 87-111.

Wallace, D.C., 2005. A mitochondrial paradigm of metabolic and degenerative diseases, aging, and cancer: a dawn for evolutionary medicine. Annu Rev Genet 39, 359-407.

Walsh, D.M., Tseng, B.P., Rydel, R.E., Podlisny, M.B., Selkoe, D.J., 2000. The oligomerization of amyloid beta-protein begins intracellularly in cells derived from human brain. Biochemistry 39, 10831-9. 


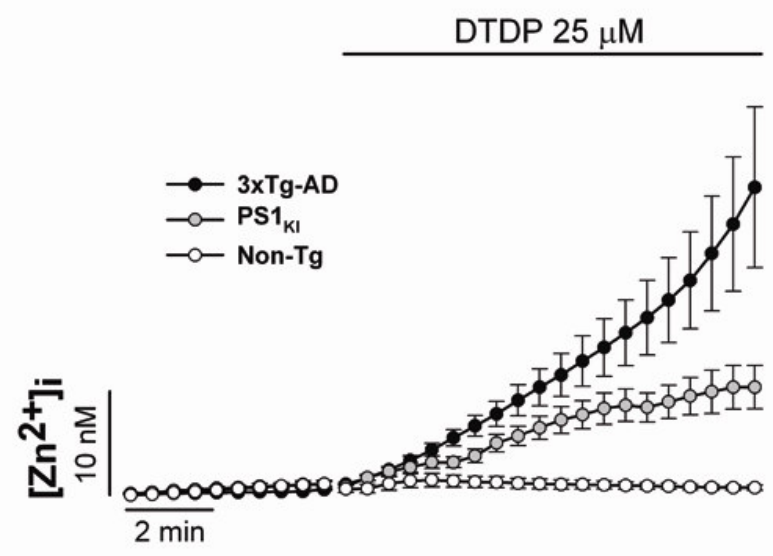



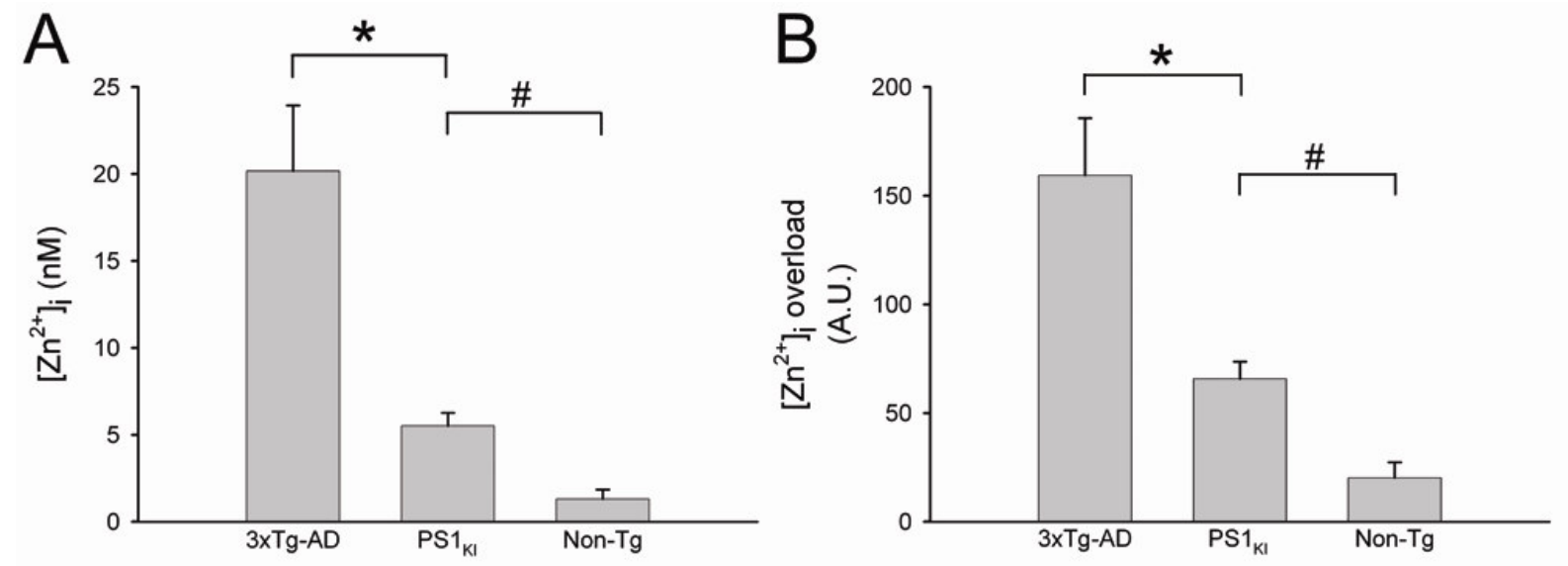